\title{
Лихачева Е.Н.
}

\author{
К вопросу о воспитании и обучении детей, \\ испытывающих трудности при усвоении дошкольной \\ образовательной программы в традиционных условиях \\ дошкольного образовательного учреждения
}

В настоящее время часть детей с задержанным уровнем психического развития являются воспитанниками не специализированных, а массовых детских дошкольных учреждений. Осуществляя воспитание и обучение таких детей в дошкольных образовательных учреждениях, воспитатель испытывает определенные сложности. Высокой и полной реализации условия повышения профессионального уровня воспитателей детских садов в вопросе обучения и воспитания таких детей должны способствовать институты повышения квалификации учителей.

Ключевые слова: ребенок, воспитание, обучение, воспитатель, трудности, институт.

Основополагающими условиями роста общественного благополучия, национальной безопасности любой страны являются развитие общеобразовательной системы, повышение уровня образованности, как населения в целом, так и качества образования каждого члена общества.

Фундаментом всего образовательного процесса является дошкольное образование. Особенностью периода дошкольного детства является то, что он обеспечивает общее развитие, служащее фундаментом для приобретения в дальнейшем любых специальных знаний и навыков, а также усвоения различных видов деятельности. За первые 6-7 лет жизни происходит интенсивное психическое развитие ребенка. За этот период он усваивает все основные виды человеческих действий, овладевает развернутой связной речью, устанавливает взаимоотношения со сверстниками. У него формируется познавательная деятельность: совершенствуется внимание, развиваются различные виды памяти, постепенно он овладевает словесно-логическим мышлением. В дошкольном возрасте развиваются потребности и формируются на этой основе разнообразные интересы. Путь развития потребностей за этот период весьма значителен - от органических, удовлетворение которых необходимо для поддержания жизни, до социальных (в деятельности, общении), в основе которых лежит стремление ориентироваться в окружающей ребенка действительности, исследовать ее. В своей деятельности дошкольник проходит путь от интереса к процессу совершения действий до интереса к результатам своей деятельности, когда появляется определенная целеустремленность в действиях: ребенок постепенно начинает видеть цель и выбирает способы, обеспечивающие ее достижение. В сфере общения и установления контактов с другими людьми все более заметно проявляется способность строить эти отношения дифференцированно, 
на основе осознания того, что можно и что нельзя. К концу дошкольного детства у ребенка накапливается некоторый социальный опыт и знания, определяющие его готовность к поступлению в школу.

В настоящее время в Республике Казахстан в дошкольном образовании имеется ряд проблем, среди которых особую актуальность приобретает проблема доступности и качества дошкольного образования. При этом возможность для равного доступа детей к дошкольному образованию выражается не только в уровне финансирования, но и в необходимости создания различных моделей дошкольного образования. В свою очередь, качество дошкольного образования нельзя рассматривать с точки зрения наличия в группах хорошо обученных детей. Вопрос повышения качества должен решаться, прежде всего, за счет роста показателей развития, обучения и воспитания каждого ребенка [9].

Данные положения в области образования обусловлены тем, что в настоящий момент определенная часть детей дошкольного возраста испытывает трудности при усвоении программного материала в силу своих индивидуальных возможностей. Действительно, в дошкольный период жизни ребенка весьма заметно проявляются не только общие возрастные черты, но и существенные индивидуальные различия, касающиеся, прежде всего, темпа психического развития. У отдельных детей наблюдается опережение психического развития, а у некоторых - наоборот, его задержка, затрудняющая процесс обучения и воспитания.

Задержка психического развития (далее ЗПР) - синдром временного отставания развития психики в целом или отдельных функций (моторных, сенсорных, речевых, эмоционально-волевых), замедленного темпа реализации закодированных в генотипе свойств организма $[2,3]$.

Анализ педагогической характеристики ребенка с ЗПР дошкольного возраста выявил следующие особенности.

Запас знаний ребенка дошкольного возраста с ЗПР об окружающем мире ограничен. Они плохо осведомлены даже в отношении тех явлений, с которыми неоднократно встречались в жизни: сезонные изменения в природе, состав семьи и труд её членов, различные признаки конкретных предметов и др. Дошкольники с ЗПР не имеют многих элементарных математических знаний, умений и навыков. Речь детей с ЗПР, хотя и удовлетворяет потребностям повседневного общения и не имеет грубых нарушений в произношении, лексики и грамматического строя, отличается бедностью словаря и синтаксических конструкций. У них недостаточно развит также фонематический слух: для них характерны затруднения в понимании художественных произведений, причинно-следственных и других связей. У подавляющего числа детей наблюдается низкий уровень элементарных трудовых умений и навыков, например, в работе с бумагой, конструктором, в самообслуживании отмечаются моторные затруднения [1, 4, 6, 7].

В настоящее время часть детей с задержанным уровнем психического развития являются воспитанниками не специализированных, а массовых детских дошкольных учреждений. Данное явление обусловлено рядом причин: 
- низкий уровень дошкольной диагностики детей с ограниченными возможностями. Дошкольный возраст - решающий в процессе становления фундаментальных образований личности. Это период, который еще сохраняет сензитивность (чувствительность) для формирования базовых основ личности, достижения оптимального уровня становления детей и позволяет последним на более раннем этапе своего формирования влиться в среду нормально развивающихся сверстников, тем самым избежать наслоения последующих (вторичных) нарушений. Однако основная масса (более 80 \%) детей поступает в психолого-медико-педагогические консультации (ПМПК), а, значит, попадает в поле зрения практической деятельности специалистов лишь к моменту поступления в школу [8];

- охват системой педагогической коррекционной поддержки лишь части нуждающихся детей, в силу несоответствия числа специальных дошкольных учреждений числу детей с ограниченными возможностями.

Статистические показатели образования детей с ограниченными возможностями за последние пять лет дают возможность выявить основную, негативную тенденцию роста несоответствия между увеличением числа нуждающихся в данном обучении и уменьшением реального охвата таким обучением. В настоящее время в республике выявлено более 150 тыс. детей с ограниченными возможностями. При этом эффективным специальным образованием охвачено лишь 23,3 \% детей [5];

- низкий уровень специализированной помощи детям со слабо выраженными нарушениями.

Одной из слабых сторон целенаправленной педагогической помощи является помощь детям со слабовыраженными нарушениями, к которым и относятся дети с ЗПР. В деятельности образовательных и лечебно-профилактических учреждений, в научных исследованиях акцент делается на больных и здоровых, а «стертые» случаи, когда ребенка не считают больным, но его развитие не совсем укладывается в понятие нормального, исследованы недостаточно. Педагоги и врачи уделяют мало внимания этим детям. Вузовская подготовка специалистов дошкольного образования не предполагает получение знаний по специальной педагогике и специальной психологии, а, следовательно, и не позволяет им оказывать эффективную помощь нуждающимся детям [5].

Осуществляя воспитание и обучение таких детей в дошкольных образовательных учреждениях, воспитатель испытывает определенные сложности.

Так, результаты проведенного нами анкетирования воспитателей общеобразовательных дошкольных учреждений города Караганды и карагандинской области Республики Казахстан показали, что 80 \% воспитателей сталкивались в своей деятельности с детьми, имеющими трудности при усвоении дошкольной образовательной программы. Решение данной проблемы воспитатели находили: в самообразовании - 41 \% (при этом отмечался недостаток учебно-методической литературы по данному вопросу), в получении консультаций у специалистов - 17 \% 
(в данном вопросе отмечалась неформальная сторона получения консультаций), в предоставлении права решать эту проблему родителям - $15 \%$.

Как видно, многие специалисты дошкольных учреждений недостаточно вооружены знаниями об особенностях психофизического развития детей, испытывающих трудности при усвоении дошкольной образовательной программы. В практике работы детских садов эти особенности часто не учитываются. Внимание воспитателей, как правило, концентрируется лишь на несформированности того или иного навыка или умения. Замечая какие-либо трудности, воспитатели стремятся помочь ребенку путем дополнительных занятий, постоянного усиленного контроля всего педагогического процесса. При интенсивной тренировке ребенок может достигнуть определенных результатов, но это будет стоить больших физических и нервно-психических затрат. Одновременно с этим при длительном переутомлении у ребенка вырабатывается стойкое отвращение к обучению и осторожно-пассивный тип поведения, при котором он не стремится достичь большего.

Высокой и полной реализации условия повышения профессионального уровня воспитателей детских садов в вопросе обучения и воспитания детей, испытывающих трудности при усвоении дошкольной образовательной программы, могут способствовать институты повышения квалификации учителей. В настоящее время придается большое значение процессу переподготовки и повышения квалификации педагогических кадров. Среди основных направлений этой работы выделяется усовершенствование содержания образовательных программ. На современном этапе данные образовательные программы должны быть ориентированы на формирование у специалистов навыков поисковой, исследовательской и творческой деятельности в работе с различной категорией детей. В этой связи в учебный процесс Карагандинского областного института повышения квалификации и переподготовки государственных служащих и работников образования (Республика Казахстан) был внедрен курс лекций, целью которого является раскрытие психологопедагогических механизмов развития детей. Данный курс охватил такие вопросы, как: изучение психолого-педагогической характеристики детей, испытывающих трудности при усвоении дошкольной образовательной программы, обучение воспитателей методикам психолого-педагогического диагностирования, описание системы индивидуально-коррекционной работы с детьми данной категории, а также методы и приемы работы с семьей ребенка, испытывающего трудности при усвоении дошкольной образовательной программы.

Основными формами занятий данного курса были лекции, семинары, практические занятия. Лекции предусматривают повышение уровня знаний воспитателей в области обучения, воспитания и развития детей, испытывающих трудности при усвоении дошкольной образовательной программы. Семинары имеют задачу обсуждения воспитателями дошкольных учреждений (под руководством преподавателя) самостоятельно подготовленных ими докладов по вышеуказанной теме. Семинары позволяют слушателям более углубленно и детально изучить предлагаемую тему, а также расширить ее границы, добиться творческого подхода в решении 
предлагаемых вопросов. Практические занятия способствуют приобретению и совершенствованию воспитателями навыков при обучении и воспитании детей, испытывающих трудности при усвоении дошкольной образовательной программы.

Содержание этого курса включает четыре основных блока.

1. Изучение психолого-педагогической характеристики дошкольников, испытывающих трудности при усвоении дошкольной образовательной программы.

2. Изложение теории и методики психолого-педагогической диагностики детей возраста.

3. Описание системы индивидуально-коррекционной работа по компенсации недостатков развития.

4. Изложение материала по вопросу организации работы воспитателя с семьей ребенка, испытывающего трудности при усвоении дошкольной образовательной программы.

Наполнение блоков лекциями, семинарами, практическими занятиями представлено следующим образом.

Первый блок. Изучение психолого-педагогической характеристики дошкольников, испытывающих трудности при усвоении дошкольной образовательной программы:

- истоки индивидуальности и их учет в педагогической деятельности (лекция, 2 часа);

- психолого-педагогическая характеристика детей дошкольного возраста с 3ПР (лекция, 2 часа);

- психолого-педагогическая классификация детей дошкольного возраста с ЗПР (лекция, 2 часа);

- соотношение первичных и вторичных дефектов в структуре задержанного развития (лекция, 2 часа);

- учет индивидуальных особенностей детей (семинар, 1 час).

Второй блок. Изложение теории и методики психолого-педагогической диагностики детей возраста:

- особенности памяти детей дошкольного возраста с 3ПР (лекция, 2 часа);

- особенности восприятия детей дошкольного возраста с ЗПР (лекция, 2 часа);

- особенности мышления детей дошкольного возраста с 3ПР (лекция, 2 часа);

- особенности внимания детей дошкольного возраста с 3ПР (лекция, 2 часа);

- особенности эмоционально-волевой сферы детей дошкольного возраста с 3ПР (лекция, 2 часа);

- изучение (психолого-педагогическая диагностика) детей дошкольного возраста с 3ПР (семинар, 2 часа).

Третий блок. Описание системы индивидуально-коррекционной работа по компенсации недостатков развития: 
- система коррекционной помощи детям дошкольного возраста с 3ПР (лекция, 2 часа);

- организация работы воспитателя по осуществлению процесса обучения и воспитания детей, испытывающих трудности при усвоении дошкольной образовательной программы (лекция, 2 часа);

- личность воспитателя, работающего с ребенком дошкольного возраста, испытывающего трудности при усвоении дошкольной образовательной программы (семинар, 2 часа);

- развитие познавательных процессов ребенка дошкольного возраста, испытывающего трудности при усвоении дошкольной образовательной программы (практическое занятие, 1 час);

- развитие эмоционально-волевой сферы ребенка дошкольного возраста, испытывающего трудности при усвоении дошкольной образовательной программы (практическое занятие, 1 час);

- развитие мелкой моторики ребенка дошкольного возраста, испытывающего трудности при усвоении дошкольной образовательной программы (практическое занятие, 1 час).

Четвертый блок. Изложение материала по вопросу организации работы воспитателя с семьей ребенка, испытывающего трудности при усвоении дошкольной образовательной программы:

- педагогическая работа с родителями ребенка дошкольного возраста, испытывающего трудности при усвоении дошкольной образовательной программы (лекция, 2 часа);

- единство осуществления индивидуального подхода в детском саду и семье (лекция, 2 часа).

Занятия-семинары проводились в режиме работы групп. Каждой группе воспитателей предлагалось рассмотреть одну из сторон изучаемой темы. При проведении практических занятий опора была на практический опыт воспитателей, а также на теоретическую базу, полученную ими при прослушивании курса. Практические занятия также проходили в групповом режиме, где каждая группа воспитателей получала определенное задание, решение которой требовало выработку новых и совершенствование имеющихся практических навыков. Итогом каждого практического занятия была защита группой своего проекта по предложенной теме. Остальные группы при этом выступали при этом в качестве оппонентов.

Результатом внедрения курса лекций в учебный процесс Карагандинского Областного института повышения квалификации и переподготовки государственных служащих и работников образования явилось повышение уровня знаний у воспитателей в вопросе психофизиологических особенностей детей, испытывающих трудности при усвоении дошкольной образовательной программ. Одновременно с этим воспитатели овладели методикой психолого-педагогической диагностики 
детей дошкольного возраста, методикой проведения коррекционных занятий, направленных на развитие психических процессов, освоили методы и приемы работы с родителями указанной категории детей.

Разработка и внедрение курса лекций в учебный процесс института не решает всей проблемы, необходима дальнейшая ее разработка. Одним из направлений этой работы должно стать ее решение на уровне подготовки специалистов высшими учебными заведениями.

\section{Литература}

1. Выготский Л.С. К вопросу о компенсаторных процессах в развитии умственно отсталого ребенка // Собр. соч. в 6 т. Т. 5. - М.: Педагогика, 1983.

2. Дети с отклонениями в развитии / под ред. Т.А. Власовой, М.С. Певзнер. M., 1971.

3. Мастюкова Е.М. Ребенок с отклонениями в развитии. - М.: Просвещение, 1992.

4. Обучение с задержкой психического развития. Пособие для учителя / под ред. Т.А. Власовой, В.И. Лубовского. - М., 1981.

5. О введении в действие Типового положения о психолого-медико-педагогической консультации // Приказ Министерства образования, культуры и здравоохранения Республики Казахстан № 43 от 02.02.1998 г.

6. Пускаева Т.Д. Возрастные особенности структуры познавательной деятельности детей с задержкой психического развития. - М., 1984.

7. Слепович Е.С. Игровая деятельность дошкольников с ЗПР. - М.: Педагогика, 1990.

8. Сулейменова Р.А., Хакимжанова Г.Д. Психофизическое здоровье и развитие детей и подростков в Республике Казахстан. Проблемы и перспективы. - Алматы, 1997.

9. Фалюшина Л.И. Управление качеством образовательного процесса в дошкольном образовательном учреждении. Пособие для руководителей ДОУ. М.: АРКТИ, 2004. 